\title{
Visitors' Perception towards Putrajaya Wetland, Malaysia
}

\author{
Che Bon Ahmad ${ }^{1 *}$, Rabiatul Adawiyah Nasir ${ }^{1}$, Annur Soleha Ahmad ${ }^{1}$, Jamalunlaili Abdullah ${ }^{2}$ \\ ${ }^{1}$ Centre of Studies, Park and Amenity Management, Faculty of Architecture Planning and Surveying, Universiti Teknologi MARA 40450 Shah \\ Alam, Malaysia \\ ${ }^{2}$ Centre of Studies, Town and Regional Planning, Faculty of Architecture Planning and Surveying, Universiti Teknologi MARA 40450 Shah Alam, \\ Malaysia
}

\begin{abstract}
Putrajaya Wetland (PW) is representing the dream of urban living, within its harmonies and refreshing environment; a place for urban people to unwind. However, starting in 2014, the number of visitors started decreasing. Thus, this research is to find out whether or not the attraction attributes, services and facilities provided contribute to the problem. Interviews with the PW management and questionnaire survey to visitors were carried out. The findings show that the attraction attributes, services and facilities at PW are up to date. Hence, it is suggested that there may be other factors causes the decreasing number of visitors to PW.

(C) 2016. The Authors. Published for AMER ABRA by e-International Publishing House, Ltd., UK. This is an open access article under the CC BY-NC-ND license (http://creativecommons.org/licenses/by-nc-nd/4.0/).

Peer-review under responsibility of AMER (Association of Malaysian Environment-Behaviour Researchers), ABRA (Association of Behavioural Researchers on Asians) and cE-Bs (Centre for Environment-Behaviour Studies), Faculty of Architecture, Planning \& Surveying, Universiti Teknologi MARA, Malaysia.
\end{abstract}

Keywords: Visitors' perception;; Putrajaya Wetlands; Malaysia

\section{Introduction}

Based on Ramsar Convention, wetland includes all lakes and rivers, underground aquifers, swamps and marshes, wet grasslands, peat lands, oases, estuaries, deltas and tidal flats, mangroves and other coastal areas, coral reefs, and all human-made sites such as fish ponds, rice paddies, reservoirs and salt pans. Wetlands are described as 'Kidney of the Planet' because of their role in cleansing the water that passes through the sediments, chemical and other pollutants.

\footnotetext{
${ }^{*}$ Che Bon Ahmad. Tel.: +6-03-5544-4354

E-mail address: chebon848@salam.uitm.edu.my
}

2398-4287 @ 2016. The Authors. Published for AMER ABRA by e-International Publishing House, Ltd., UK. This is an open access article under the CC BY-NC-ND license (http://creativecommons.org/licenses/by-nc-nd/4.0/).

Peer-review under responsibility of AMER (Association of Malaysian Environment-Behaviour Researchers), ABRA (Association of Behavioural Researchers on Asians) and CE-Bs (Centre for Environment-Behaviour Studies), Faculty of Architecture, Planning \& Surveying, Universiti Teknologi MARA, Malaysia.

DOI: http://dx.doi.org/10.21834/e-bpj.v1i3.365 
Putrajaya Wetland (PW) is the first man-made wetland in Malaysia and the largest constructed freshwater wetland in the tropics. The scale model of PW represents the dream of urban living, within its harmonies and refreshing environment incorporating genuine open spaces, parks and wetlands. It was begun to construct in March 1997 and was completed in August 1998. Their primary function is to ensure that the water entering the lake meets the standard set by management - Putrajaya Corporation. The wetland cells separated by rock weirs, PW were constructed by damming part of the rivers. It covers a total area of 650 hectare which consists of constructing marsh areas and lake systems. The main function of PW is a natural filtering system where by the wetland cells will trap and remove sediment and in- flowing pollutants from upstream catchments before they enter the lake. When the sediment is deposited nutrients which are usually associated with particles of sediments it is taken up by the wetland vegetation connected by the chemical and biological process. Other than that PW play the roles as a function in flood mitigation, it's also the most important site for flora and fauna conservation.

Besides, it's offered a suitable site for research and a tourist destination. Among the attractions and facilities available here include nature trails, a three-story lookout tower, and artificial water bird ponds, viewing desk, a wetland plant nursery and shelter huts. PW also have their interpretation center, which called the Nature Interpretive Centre (NIC) enables visitors to gain hands- on and educational experience on wetlands through a slide and video presentations, poster displays, exhibits of wetland flora and fauna, a wetland plant herbarium, etc. there are a few checkpoints that might be attracted to the visitor such as flamingo pond and swan lake.

However, the visitors' population has decreased drastically from 147,482 in 2013 to 70,772 in 2014 (Annual Report, Putrajaya Corporation, 2013).

\subsection{Aim/ Purpose of study}

This research is to find out whether or not the attraction attributes, services and facilities provided at PW affect the decreasing of visitors' population. The research objectives are to determine the visitors' perception on the PW; to investigate the factors influencing visitors' participation at PW; and to identify the visitors' satisfaction towards attraction attributes, facilities, and services provided at PW.

\section{Literature Review}

\subsection{Wetland visitation}

It is possible that people living in the urban area gain less enjoyment from some aspect of gardening and are therefore more attracted to nature areas. The simplest assumption would be that people living on small lots would spend less time in their garden and would use the wetlands (Syme, 2001). The decreasing lot size has changed the quality of life and changes the satisfaction of visitor of used the local open space. Home ownership, family size and number of the household showed a significant relationship to wetland visitation. According to (Syme, 2001) larger families with more children tended to visit wetlands less often, and the occupancy of specific block sizes tended to influence the perception of the wetland environment and, therefore, visitation. This trend has influenced Malaysian to choose wetland as their leisure destination (Ahmad, Hashim, Abdullah, \& Jaafar, 2012; Skov, 2011; Sun et al., 2015).

Wetlands offer a cheaper and low-cost alternative technology for waste water treatment. Constructed wetlands are innovated to treat low volumes of water waste loaded with easily degradable organic matter for isolated populations in urban areas. Concern over wetland losses have generated a need for the creation of wetland, which are intended to emulate the function and values of natural wetlands that have been destroyed and to make a creation of habitat to compensate for natural wetlands converted for agriculture and urban development, water quality improvement, flood control and production of food and fiber (Sim, 2003). It offers a combination of nature's beauty and state of the technology, environmental quality and aesthetic which plays a major role in its development. 


\subsection{The use of constructed wetland for waste water treatment}

There are two types of wetlands, which are constructed and natural that offer a cheaper and low- cost alternative technology for wastewater treatment. Constructed wetland treat low volumes of water waste loaded with easily degradable organic matter for isolated populations in urban areas. Because concern over wetland losses have generated a need for the creation of wetland, which is intended to emulate the function and values of natural wetlands that have been destroyed.

The purpose of constructed wetland is to make a creation of habitat to compensate for natural wetlands converted for agriculture and urban development, water quality improvement, flood control and production of food and fiber (Sim,C.H. 2003) The advantage of constructed wetland is the cheaper alternative for water waste treatment using local resources, beside aesthetically it is more landscaped looking wetland site and utilization of local products and labor, helps to reduce the operation and maintenance costs of the applied industries. This constructed wetland also could be used to clean polluted rivers and other water bodies. A wetland can serve as a wildlife sanctuary and provide habitat for wetland animals. The wetland system can also be aesthetically pleasing and serve as a public attraction sanctuary for visitors to explore its environmental and educational possibilities. In addition, PW is the first constructed wetland in Asia, which is combined nature's beauty and state of the technology, environmental quality and aesthetic plays a major role in its development. According to (Sim, C.H. 2003) the chain of wetland was designed and developed in a sustainable and balanced of the ecosystem. The layout of PW covers totals 162 hectares which consist of 24 wetland cells of various sizes separated by weirs at a different level. Wetland cell in Putrajaya was separated by rock weirs, and PW was constructed by damming part of the rivers with a series of weirs.

\subsection{Product attributes as Attraction}

Visitors' decision to visit a park depends on the park attractions 'push and pull factor'. The attraction includes park's product such as its facilities, services and programmers provide by the management. The place or park that has a lack of attraction contributes to the decline in its visitation. There are several factors associated with park visitation, and these are socio-economic background, recreational opportunities and attributes of the park that attract people (Cohen et al., 2009; Mohamed \& Othman, 2012). The roles of site attractions, advertising, flow of information and activities have influenced people's decision-making process, whereby they are more likely attracted to visit the places that have a good appeal or possess distinctive attributes such as beautiful scenery, lots of recreational opportunities or special attractions. The attractions are related to facilities, programs and services that enable the visitors to enjoy their visiting experience beside this attribute should be recognized as the park's best asset and promoted accordingly to improved visitation.

\subsection{Push and Pull Factors: Determining the Visitors' Satisfactions at Urban Recreational Area}

These recreational areas are great assets for the cities and urbanities (Mohamed \& Othman, 2012) and they are created to preserve the natural environment (Ismail, 2002), as a place for people to experience nature (Cohen 2009), to release from stress and gain a positive psychological effect. Although there is an increasing interest in the urban recreation area, it is also evident that some people do not respond well and give negative feedback such as; the place is untidy, lack of facilities and plant maintenance, unsafe for women and sometimes too crowded at a certain time (Yahya \& Mohd, 2013). Noralizawati (2009) found that the park users were dissatisfied with the sounds coming from the urbanization activities which would break their concentration while visiting the recreational park. The natural elements are one of the factors that influenced or pushed the visitors to visit the place are associated with the elements that appear as beautiful, cooling, well maintained and organized. Beside the physical characteristic, the values and benefits of the areas such as peace and quiet, relief from stress and can get close to nature are also associated with their feeling of satisfaction too. 


\subsection{Visitors experience and Wetland Parks}

According to Wang et al., (2012), customers' best experiences are when they have an overall sense of flow, which in turn requires eight elements: clear goals, immediate feedback, the match of individual skills and challenges, an inherent sense of control, loss of self-awareness, changes of time perception, purposive experience, and concentration on activity. Ecotourism experience is often discussed in relation to the definition of ecotourism, which can be seen as a type of tourism product, a way of travel, and a means to achieve sustainable development. Eagles (1992) view eco-tourism as a unique tourism product. To obtain customers' perceptions of quality, Parasuraman, Zeithaml, and Berry (1988) propose a five-dimensional framework of tangibles, reliability, assurance, empathy, and responsiveness. The action experience and aesthetic experience are the two factors that are most likely to influence the tourist experience in wetland parks. To improve action experience, an operator may develop diversified recreational activities that offer the tourist a totally different life experience. The five factors that are likely to influence the tourist experience: resource conditions, recreational activities, tourism facilities, integrated management, and related personnel.

The factors influencing visitors experiences in wetland parks in the context of an emerging economy with the relationships among service quality, experience, and revisit intention are best experiences when they have an overall sense of flow, which in turn requires eight elements: clear goals, immediate feedback, the match of individual skills and challenges, an inherent sense of control, loss of self-awareness, changes of time perception, purposive experience, and concentration on activity. To obtain customers' perceptions of quality, Cohen \& Marsh (2010) propose a five-dimensional framework of tangibles, reliability, assurance, empathy, and responsiveness.

\subsection{Wetland and Ecotourism}

Ecotourism is natural resource attractions or a combination of natural resource and cultural attractions. There are some detailed propositions for the organization of tourism in protected wetlands. According to Kusler (2006), the visitors require transportation in area, be able to access to the wetland (road, walking trails), to be able to see a wide variety of birds, other animals, plant and other attractions, wetland interpretation, guide services and food and accommodation. Sustainable tourism could make a significant contribution to the quality of the environment, economic development and the wellbeing of the host community while providing a high-quality experience for the visitor and the tourist (Lim, Mc Allen, 2003).

\subsection{Wetland ecotourism issues and challenges}

The impact of ecotourism can be identified under three major categories, namely, environment, economy and socio-culture (Wall, 2001). The key environmental issues in the tourism sector include pollution due to poor or inadequate facilities to dispose solid waste, waste water and sewerage, generation of large quantities of solid waste, beach pollution caused by disposable material and release of sewage and storm water into oceans, illegal construction of tourist amenities along the beach, unplanned construction of tourist facilities, over development process in coastal excessive demands on power due to unplanned use of electricity, solid waste accumulation at tourism sites and environmental disorder in the various cultural heritage sites (Tourism Development Project, 2005) The lack of financial and human resources directly affects implementation of the capital investment and infrastructural facilities in the development of ecotourism.

\section{Study Area}

PW is located in Presint 13, Putrajaya serves for water treatment, recreation and educational purposes (Wetland International, Malaysia and NAHRIM, 2013). The whole area of PW is 197.2 hectares and be divided into the subcomponent such as plantation area (77.7 hectares), open water (76.8 hectares), (weirs and island 9.6 hectares), flood release zone (23.7 hectares) and maintenance track ( 9.4 hectares). 


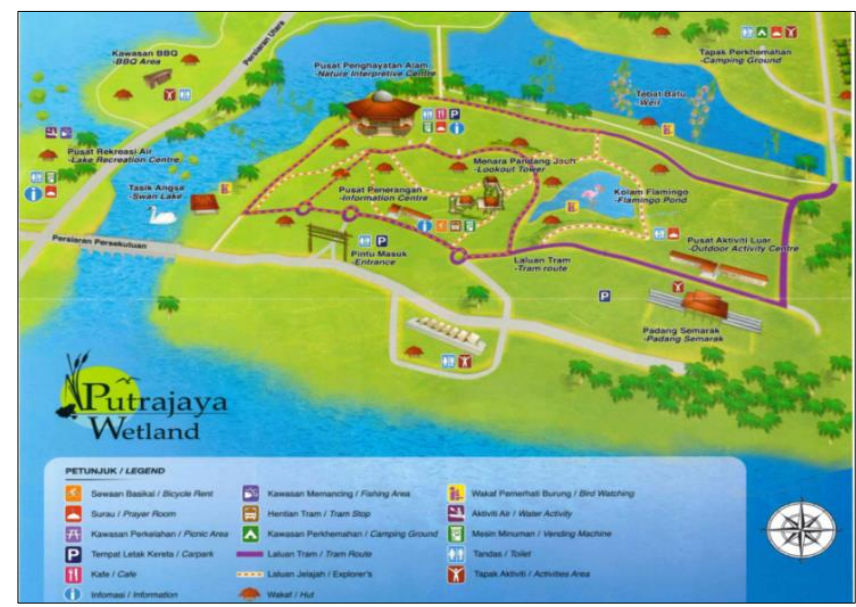

Fig.1. Map of Wetland Putrajaya Source: Department of Interpretation and Park Education, (2015)

PW plays an important role in sustaining biological diversity and they also perform vital functions such as water purification, nutrient retention, maintenance of water tables, storm protection, flood mitigation, shoreline stabilization, erosion control and groundwater recharge (Ahmad Jamalluddin Shaaban, 2013). It has made the attractions for the migrant birds and there are 32 species of rare fruits, 32 species of forest trees, 48 species of forest plantations for multiples such herbs and sense, beside there are 45 species of shrubs (Putrajaya Cooperation, 2012).

It also provides multiple facilities such as water recreation, Nature Interpretive Center, camping sites, a site for the family day, lookout tower, information center, souvenir shop, gazebo and nature trails. Below is the example of attractions attributes found at PW.

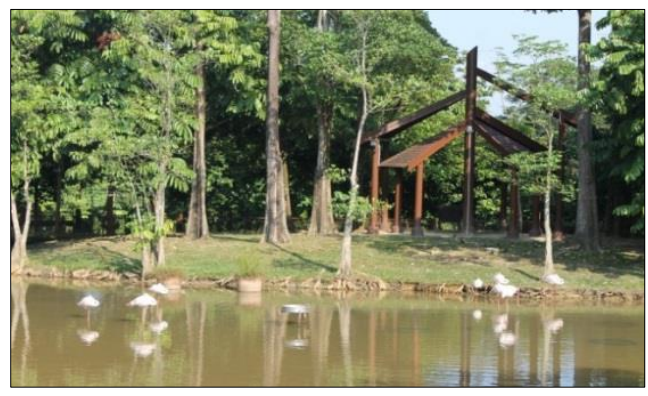

Fig.2. Campsite and Flamingo Pond, habitat for one of the five largest species in the world.

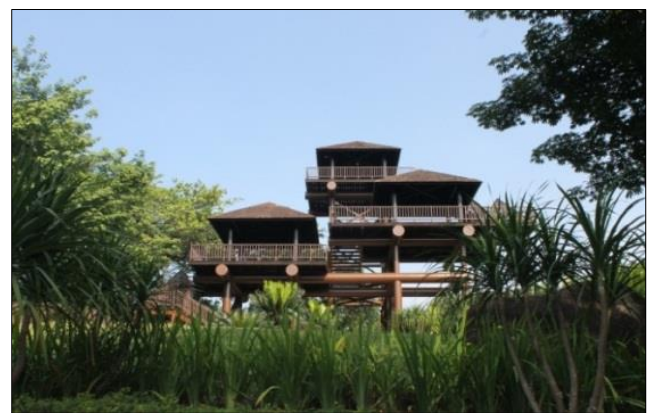

Fig. 3. 18-metres tall lookout tower mesmerized visitors by the beauty of wetlands 


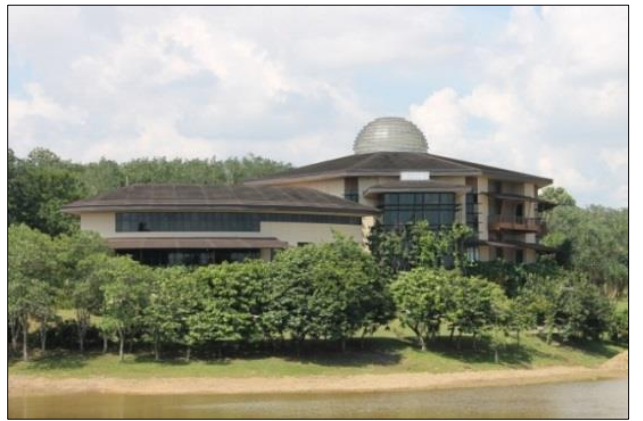

Fig. 4. Nature Interpretive Center (NIC) - The place for visitors to enrich their knowledge.

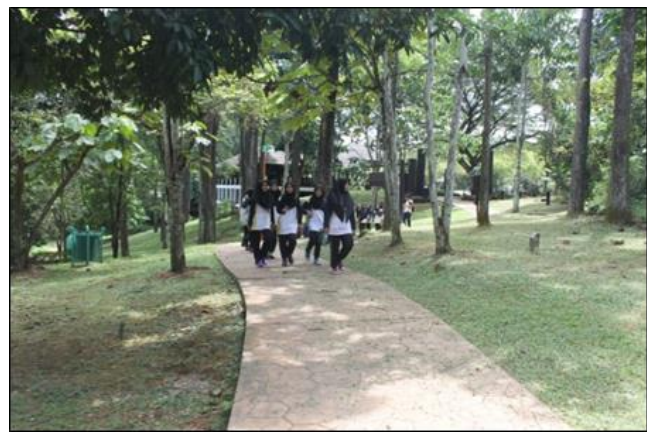

Fig. 5. Nature Trail for visitors to enjoy the nature scenery of PW
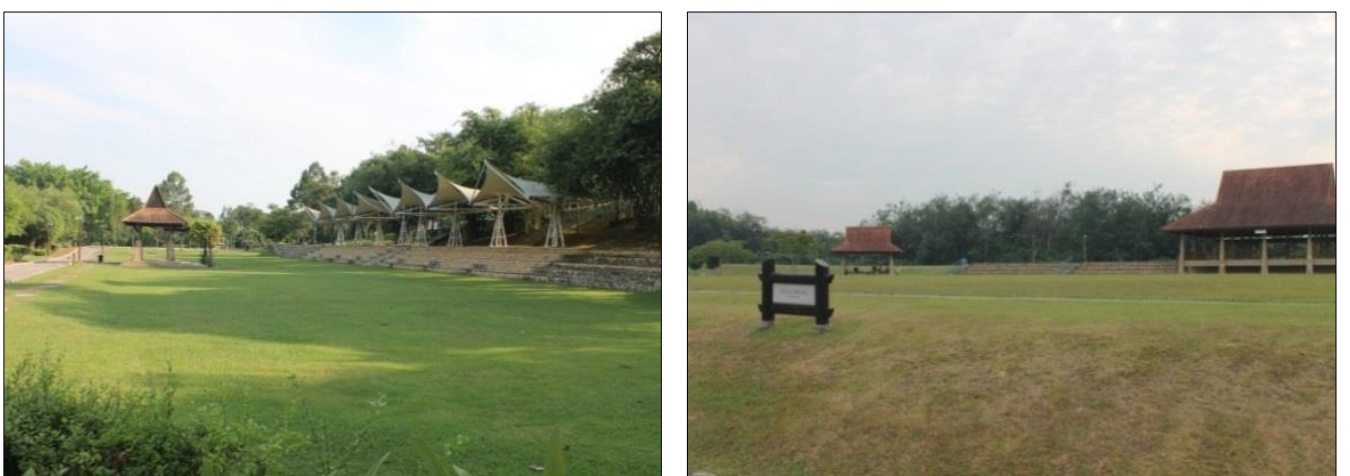

(a) (b)

Fig. 6.(a) Merbok Ground offers high capacity area for activities; (b) Padang Semarak 


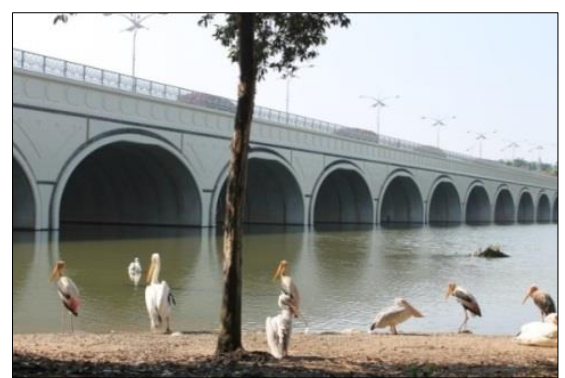

(a) (b)

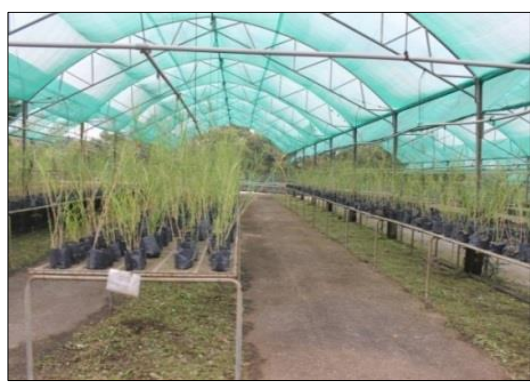

Fig. 7. (a) Swan Lake; (b) New sprout of marsh plants

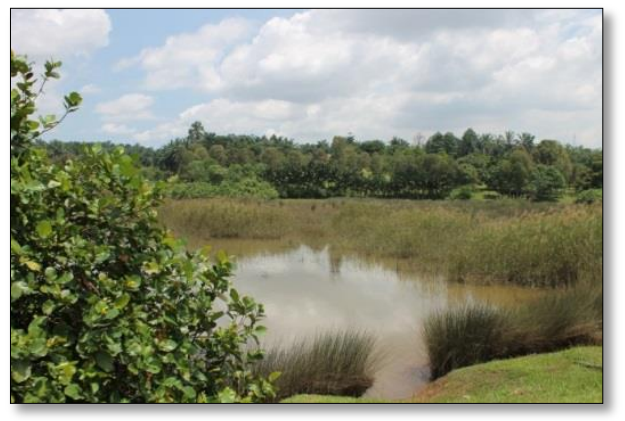

Fig. 8. Wetland Cells (marsh plant such as Giant bulrush (Scirpus grossus) and common reed (Phagmites karka)

\section{Methodology}

The methods used are in-depth personal interviews with the management and the questionnaire survey to the visitors visiting the WP. The interview is carried out with the intension to obtain a preliminary understanding of the issues regarding the topic. This is further elaborated in the questionnaire survey which covers demographic part, understanding on wetland and satisfaction on the attraction attribute, services and facilities provided. The sampling size is 357 based on a statistical table by Krejcie and Morgan (1970).

\section{Findings}

\subsection{Respondent characteristics}

There is a low significant difference in terms of gender, marital status, in-come and education level. On the other hand, most of the visitors are Malaysian and coming from outside Putrajaya area. This study also found that most of the visitors coming to PW are for recreation and leisure. The results show (55\%) of respondents were visiting PW for the first time, and $(45 \%)$ of respondents were frequent visitors. Various studies have shown that the frequent visits to a tourist destination are related to higher levels of visitor satisfaction; due to the fact that, satisfaction partly motivate these people to re-visit the same destination again (Geva and Goldman 1991; Yuksel, 2001; Tian-Coleet al., 2002; Rittichainuwat et al., 2002). 


\subsection{The attraction factors that influencing visitor's population at Wetland Putrajaya}

The overall result shows that respondents positively agree with all the attraction attributes provided at PW with the highest mean of this section are natural environment becoming the most important factor that is influencing visitor's population at PW. These recreational areas are great assets for the cities and urbanities (Sreetheran, 2007) and they are created to preserve the natural environment (Ismail, 2002), as a place for people to experience nature (Cohen et al., 2007), to release from stress and gain a positive psychological effect (Noralizawati, 2009). In addition, the constructed PW has the biggest potential for the visitors to experience the natural environment in the area of urban cities and the landscape of wetland that perceives as natural, environmentally friendly and highly aesthetic shows that encourage to the visitors to visit PW.

Most of the respondents are agreed that bird watching is one of the highest factors of attraction while visiting PW. Furthermore, the birds migrated to a wetland area in their migrated season, which started form September and April. At this time, wetland area is a pit stop for thousands of birds that came to get some food from the lakes and it is for them to regain their energy to continue their journey.

\subsection{The Visitor's Satisfaction}

The result shows $74.8 \%$ of the respondents are attracted to the services, facilities and the program that are being provided at PW. Visitor's satisfaction from the use of a tourist commodity at various destinations also depends on the products and prices on offer, as well as the quality of the services provided and the friendly attitude of the locals.

The result also shows that the natural beauty of PW encourages the respondents to revisit the park and the respondents are satisfied with the natural beauty of PW. Other than that, the respondents also satisfied with the different views Wetland Putrajaya compared to the others park in Putrajaya. Overall the respondents are satisfied with the services and facilities provided at Wetland Putrajaya. In other words, visitors who are satisfied with the services in the park have high potential to make a return visit and recommend the park to others. The level of satisfaction also was found to have the biggest influence on the decision of wheatear to revisit one destination (Campo-Martinez et al., 2009).

\section{Discussion \& Analysis}

This study offers findings which explain the role of attractions toward bringing in visitors to the park and sustain the visitation. People visit a tourist destination in order to fulfill and satisfy specific needs and desires. This shows that PW is one of the tourist destination that suitable recreation and leisure. The park management must meet the visitor expectation and knowledge level at all time. This result of this study provided the management of the park with valuable information on understanding their visitors' perceptions and the satisfaction. It also helps to manage their resources in a more specific manner. PW has the elements that are interesting to the visitors to return to PW to use the services, facilities and the program that are being provided.

The visitors' perceptions can produce information, which useful as basic monitoring for PW management, quality and development. The visitors' preferences and satisfaction of the attractions at Putrajaya Wetland can be as manual for planning and management so that the management approaches can be successful. In fact, the effective management should take into consideration of the visitor perceptions, motivations, preferences in order to fulfill their satisfaction and experience.

By determining how visitor preferences for each attraction, it perhaps contain meaningful information and could assist the park manager decision-making process towards achieving the target to increasing the number of visitors visitation. Overall from the finding suggested that majority of the visitors agreed the attractions, services and facilities at Putrajaya Wetland are sufficient. Hence, it is suggested that the decreasing number of visitors may be affected by other factors. Therefore, it requires further research to determine the factors that cause the problems. 


\section{Conclusions \& Recommendations}

The findings show the majority of visitors understand what wetland is, agreed that the attractions, services and facilities at WP are up to date. Hence, it is suggested that the other factors for example, willingness to pay for the facilities provided and et cetera may cause the problem. Thus, further research is required to unveil the factors that cause the problem.

\section{Acknowledgements}

The authors would like to extend the utmost appreciation to the respondents for their exceptional dedication and enthusiasm and for sharing their valuable time and support. This appreciation also goes to Research Management Unit, Universiti Teknologi MARA, Shah Alam, Selangor, Malaysia for the expertise and financial support. The authors also acknowledge the constructive comments for reviewing the manuscript.

\section{References}

Ahmad, C. B., Hashim, I. H. M., Abdullah, J., \& Jaafar, J. (2012). Stakeholders' Perception on Buffer Zone Potential Implementation: A Preliminary Study of Tasek Bera, M'sia. Procedia - Social and Behavioral Sciences, 50, 582-590. doi:10.1016/j.sbspro.2012.08.061

Cohen, D. A., \& Golinelli, D. (2009). Effects of Park Improvements on Park Use and Physical Activity: Policy and Programming Implications. American Journal of Preventive Medicine, 37(6), 475-480.

Cohen, D. A., \& Marsh, T. (2010). Parks and physical activity: Why are some parks used more than others? Preventive Medicine, 50(Supplement 1), S9-S12.

Ahmad Jamaluddin bin Shaaban (2013), Q\&A TO CONSTRUCTED WETLANDS, National Hydraulic Research Institue of Malaysia (NAHRIM) and Wetlands International Malaysia, CG Print Sdn.bhd, Foreword pg.6

Ibrahim, I., Aminudin, N., \& Yahya, M. A. Y. @ S. A. I. (2012). Education for Wetlands: Public Perception in Malaysia. Procedia - Social and Behavioral Sciences, 42(December 2010), 159-165. http://doi.org/10.1016/j.sbspro.2012.04.177

Mohamed, N., \& Othman, N. (2012). Push and Pull Factor: Determining the Visitors Satisfactions at Urban Recreational Area. Procedia - Social and Behavioral Sciences, 49, 175-182. http://doi.org/10.1016/j.sbspro.2012.07.016

Skov, H. (2011). UN Convention on Wetlands (RAMSAR): Implications for Human Health. In O. N. Editor-in-Chief: Jerome (Ed.), Encyclopedia of Environmental Health (pp. 496-503). Burlington: Elsevier. doi:10.1016/b978-0-444-52272-6.00656-5

Sim,C.H. (2003). The use of constructed wetlands for waterwaste treatment.Wetland International-Malayia Office.Petaling Jaya

Sun, X., Xiong, S., Zhu, X., Zhu, X., Li, Y., \& Li, B. L. (2015). A new indices system for evaluating ecological-economic-social performances of wetland restorations and its application to Taihu Lake Basin, China. Ecological Modelling, 295, 216-226. doi:10.1016/j.ecolmodel.2014.10.008

Syme, G. J., Fenton, D. M., \& Coakes, S. (2001). Lot size, garden satisfaction and local park and wetland visitation. Landscape and Urban Planning, 56(3-4), 161-170. http://doi.org/10.1016/S0169-2046(01)00179-7

Wang, W., Chen, J. S., Fan, L., \& Lu, J. (2012). Tourist experience and Wetland parks: A case of Zhejiang, China. Annals of Tourism Research, 39(4), 1763-1778. http://doi.org/10.1016/j.annals.2012.05.029

Yahaya, A., \& Mohd, A. (2013). Products attributes as attraction and as pull factor towards sustaining visitation to Putrajaya Botanical Garden. Pertanika Journal of Social Science 